\title{
Analisis Manajemen Risiko TI Pada Diskominfo Salatiga Menggunakan Cobit5 Dengan Domain Apo12
}

\author{
Hesti Ani Novita Sari*1, Yani Rahardja, S.E., M.M ${ }^{2}$, Hanna Prillysca Chernovita, S.SI., \\ M.Cs ${ }^{3}$ \\ ${ }^{1,2}$ Universitas Kristen Satya Wacana; Jl.Diponegoro no.52-60, Salatiga, Kec. Sidorejo, Kota \\ Salatiga, Jawa Tengah 50711, Telp:(0298)321212 \\ ${ }^{3}$ Program Studi Sistem Informasi, FTI UKSW, Salatiga \\ e-mail: 1682017076@student.uksw.edu, ${ }^{2}$ yani.rahardja@uksw.edu \\ 3hanna.chernovita@uksw.edu
}

\begin{abstract}
Abstrak
Dinas Komunikasi dan Informatika (DISKOMINFO) Salatiga merupakan perangkat pemerintah Kota Salatiga yang mempunyai tugas mengelola di bidang komunikasi dan informatika pada pemerintahan untuk membantu Wali kota yang mengacu pada Kementerian Kominfo. Manajemen risiko Teknologi Informasi yang tepat sangat diperlukan untuk mengurangi risiko. Risiko-risiko TI tersebut seperti server down, adanya virus pada PC, kerusakan atau kehilangan data dan lain sebagainya. Melihat dari permasalahan tersebut, dalam penelitian ini memaparkan mengenai analisis manajemen risiko TI pada DISKOMINFO menggunakan kerangka kerja COBIT 5 dengan domain APO (Align, Plan, Organize) 12. Hasil penelitian memaparkan risiko-risiko yang berpotensi membahayakan dan memberikan rekomendasi sebagai solusi untuk menekan potensi kerugian yang dapat timbul.
\end{abstract}

Kata kunci-APO 12, COBIT 5, manajemen risiko.

\section{Abstract}

The Salatiga Communications and Information Office (DISKOMINFO) is one of the Salatiga City Government apparatus which has the task of managing the communication and information technology sector in the government to assist the mayor who refers to the Ministry of Communication and Information. Proper Information Technology risk management is needed to reduce risk. IT risks such as server down, virus on PC, damage or loss of data and so on. Seeing these problems, this study describes the analysis of IT risk management at DISKOMINFO using the COBIT 5 framework with the APO domain (Align, Plan, Organize) 12. The results of the study describe potentially detrimental risks and provide recommendations as solutions to reduce potential risks. losses that may arise.

Keywords-APO 12, COBIT 5, risk management.

\section{PENDAHULUAN}

Teknologi informasi (TI) mengalami perkembangan dari masa ke masa. Pemanfaatan teknologi informasi juga semakin meluas dari berbagai kalangan meliputi, Bisnis, Pendidikan, Perusahaan, tak terkecuali pada Pemerintahan. Peran penting TI juga dimanfaatkan DISKOMINFO Salatiga dalam melakukan proses bisnisnya. Jika dalam penggunaan Teknologi Informasi pada proses bisnis mengalami kendala atau masalah maka akan menimbulkan risiko dalam berjalanya proses bisnis DISKOMINFO yang dapat menghambat proses berlangsungnya 
proses bisnis. Maka dari itu, diperlukannya Analisis Manajemen Risiko Teknologi Informasi untuk mengurangi, mencegah, dan menangani risiko TI.

Analisis manajemen risiko TI dapat dilakukan menggunakan kerangka kerja COBIT 5. Dalam penelitian ini mencakup analisis manajemen risiko pada TI menggunakan salah satu domain COBIT 5 yaitu APO (Align, Plan, and Organise)12. APO12 dapat digunakan untuk melakukan pengelolaan risiko Teknologi informasi DISKOMINFO menggunakan 6 subdomain yang berperan dalam pengelolaan risiko Teknologi Informasi.

Dalam penelitian ini terdapat proses analisis menggunakan domain APO12 yaitu proses mengidentifikasi, menilai dan mengatur risiko TI. Melalui proses analisis tersebut diharapkan dapat menentukan tindakan terhadap risiko TI secara cepat dan tepat agar terhindar dari dampak risiko. Sehingga dengan adanya manajemen risiko yang tepat, kedepannya DISKOMINFO dapat menggunakan hasil penelitian sebagai acuan dalam melakukan manajemen risiko dengan adanya rekomendasi tanggapan terhadap risiko yang dihasilkan pada penelitian ini.

Penelitian-penelitian terdahulu yang dilakukan oleh Prilly peshaulia Thenu, dkk., dengan judul "Analisis Manajemen Risiko Teknologi Informasi Menggunakan Cobit 5 (Studi Kasus: PT Global Infotech)". Tujuan penelitian ini yaitu mengetahui efektifitas dalam pemanfaatan COBIT 5 di perusahaan agar berperan untuk meminimalisir dan mengelola risiko TI. Manfaat yang diharapkan dari penelitian ini yaitu dapat mengurangi kerugian bagi perusahaan dengan menjadikan rekomendasi dari penelitian sebagai panduan bagi perusahaan untuk mengelola risiko TI.[1]

Penelitian serupa yang di lakukan oleh Fardiana Karuniawati, S.T., M.Kom, dkk., yang berjudul "Penggunaan COBIT 5 untuk Penilaian Risiko Dalam Situs E-Marketplace di Indonesia". Penelitian ini berfokus pada pengukuran risiko sistem E-Marketplace dengan menggunakan Cobit 5. Penelitian ini menghasilkan pengukuran capability level pada domain EDM 03 dan APO12 yang kemudian dapat diambil beberapa kesimpulan penelitian.[2]

Penelitian sebelumnya oleh Hery Purwanto, dkk., yang berjudul "Penerapan Framework COBIT 5 pada Tata Kelola Teknologi Informasi PT PINDAD (Persero) (Studi Kasus : Domain APO 11 \& APO12)" tujuan yang ingin dicapai dari penelitian ini adalah menentukan tingkat kapabilitas dan menyusun rencana teknologi informasi dengan rencana strategis perusahaan yang ada pada PT PINDAD Persero dengan framework COBIT 5. Hasil dari penelitian ini berdasarkan pada pengukuran sebuah kerangka kerja APO 11 dan APO12 terhadap kematangan perusahaan dalam mengelola teknologi informasinya didapat pengukuran mencapai level 3, sehingga untuk mencapai level Fully Archived maka terdapat beberapa usulan.[3]

Penelitian lainya mengenai "Evaluasi Manajemen Risiko Teknologi Informasi pada Badan Perencanaan, Penelitian dan Pengembangan (Barenlitbang) Kota Malang Menggunakan Cobit 5 Domain EDM03 dan APO12" oleh Agatha Shella Agtika dkk. Penelitian ini bertujuan untuk mengetahui sejauh mana penerapan manajemen TI pada Lembaga yang bersangkutan pada tahapan perencanaan dan tahap evaluasi kerja. Rekomendasi yang dihasilkan meliputi 6 rekomendasi yang dapat digunakan oleh pihak yang bersangkutan untuk memaksimalkan penerapan Teknologi Informasi dan optimalisasi satgas pengendalian internal dalam pengendalian risiko.[4]

\subsection{Kajian Pustaka}

\section{METODE PENELITIAN}

\subsubsection{Manajemen Risiko Teknologi Informasi}

Manajemen Risiko TI merupakan proses mengenai pemahaman, penilaian dan pengambilan kesimpulan terhadap risiko terkait Teknologi Informasi dengan tujuan meningkatkan keberhasilan dalam melakukan proses bisnis perusahaan dan meminimalisir 
kegagalan maupun adanya kesalahan pada TI. Manajemen risiko berperan dalam peningkatan kinerja, memudahkan pengambilan keputusan dan memungkinkan untuk melakukan perbaikan yang tepat dan terus-menerus. Risiko tersebut berhubungan dengan kepemilikan, operasional, dan dampak dalam penggunaan Teknologi Informasi.[5]

\subsubsection{COBIT 5}

COBIT 5 merupakan kerangka kerja yang berfungsi untuk pengendalian internal tata kelola dan manajemen Teknologi Informasi perusahaan dalam mencapai enterprise goals (tujuan perusahaan). Model referensi proses pada COBIT 5 membagi praktik dan aktivitas yang berhubungan dengan TI ke dalam dua area utama yaitu:

- Area pertama merupakan Tata kelola, domain tata kelola ini meliputi evaluasi, arahan, dan pengawasan (Evaluate, Direct, dan Monitor (EDM)).

- Manajemen, berhubungan dengan tanggung jawab pada bidang merencanakan, merencanakan, membangun, menjalankan, dan mengawasi (Plan, Build, Run, and Monitor (PBRM)).[6]

Cobit 5 memiliki 5 domain yaitu :

a. Evaluate, Direct, and Monitor (EDM)

b. Align, Plan and Organise (APO)

c. Build, Acquire, and Implement (BAI)

d. Deliver, Service and Support (DSS)

e. Monitor, Evaluate, and Assess (MEA).[7]

\subsubsection{APO12}

Dalam penelitian ini menggunakan domain APO, domain ini melingkupi strategi dan taktik, serta mengidentifikasi cara terbaik dimana TI dapat berkontribusi dalam pencapaian tujuan bisnis. APO sendiri memiliki 13 domain proses, domain proses yang digunakan dalam penelitian ini yaitu APO12 (manage risk). Domain APO ini merupakan domain yang mencakup bagaimana penggunaan teknologi informasi untuk membantu mencapai tujuan organisasi yaitu Dinas Komunikasi dan Informatika Salatiga. APO12 memiliki 6 subdomain antara lain :

- APO12.01 Collect Data / mengumpulkan data terkait risiko.

- APO12.02 Analyse Risk / Menganalisis risiko atau mengembangkan resiko.

- APO12.03 Maintain A Risk Profile / Mememlihara atau Menjaga profil risiko

- APO12.04 Articulate Risk / Mengkomunikasikan risiko.

- APO12.05 Define a Risk Management Action Portofolio / Mendefinisikan portfolio tindakan Manajemen risiko.

- APO12.06 Respond to Risk / Menanggapi risiko.[1]

\subsection{Tahap Penelitian}

Metode penelitian yang digunakan yaitu metode penelitian kuantitatif yaitu pendekatan penelitian yang mencakup landasan survei pada risiko TI dan metode kualitatif yaitu mencakup data pemahaman terhadap fenomena risiko TI sebelum peneliti terjun di lapangan dengan melakukan studi pendahuluan untuk menentukan fokus penelitian.[8] Berikut alur metode penelitian yang digunakan: 


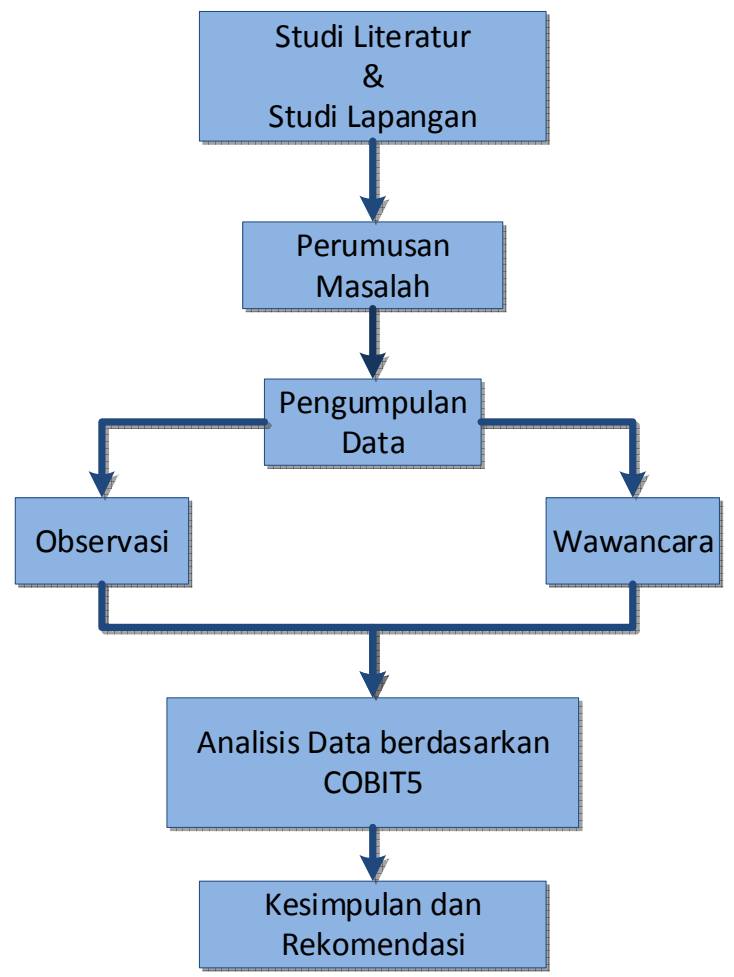

Gambar 1. Alur Metode Penelitian

\subsubsection{Studi Literatur dan Studi Lapangan.}

Tahap awal penelitian ini yaitu dimulai dari studi literatur terhadap jurnal ataupun materi mengenai COBIT 5 dan manajemen risiko TI. Dan juga melalui studi lapangan, dengan mengamati proses bisnis di Dinas Komunikasi dan Informatika.

\subsubsection{Perumusan masalah}

Mendefinisikan masalah yang akan ditentukan sebagai fenomena untuk di angkat dalam penelitian yaitu berupa risiko-risiko Teknologi Informasi di Dinas Komunikasi dan Informatika.

\subsubsection{Pengumpulan Data}

Temuan rumusan masalah, selanjutnya harus di lengkapi dengan data-data untuk dapat dianalisis. Metode pengumpulan data pada penelitian ini yaitu dengan melakukan wawancara kepada pihak-pihak yang berwenang dan observasi dengan mengamati proses terkait teknologi informasi di Dinas Komunikasi dan Informatika. Data yang di dapat berupa data primer yaitu data dari hasil wawancara maupun sekunder yaitu data yang berasal dari publikasi DISKOMINFO di internet.

\subsubsection{Analisis Data berdasarkan COBIT 5}

Analisis data terhadap temuan risiko TI berdasarkan pedoman COBIT 5, Menggunakan domain APO12 yaitu manage risk. Dengan menggunakan 6 subdomain APO 12 yaitu APO 12.01 sampai subdomain $A P O 12.06$.

6 subdomain tersebut yaitu sebagai berikut :

- APO12.01 Collect Data / mengumpulkan data terkait risiko.

- APO12.02 Analyse Risk / Menganalisis risiko atau mengembangkan resiko.

- APO12.03 Maintain A Risk Profile / Mememlihara atau Menjaga profil risiko. 
- APO12.04 Articulate Risk / Mengkomunikasikan risiko.

- APO12.05 Define a Risk Management Action Portofolio / Mendefinisikan portfolio tindakan Manajemen risiko.

- APO12.06 Respond to Risk / menanggapi risiko [1].

\section{HASIL DAN PEMBAHASAN}

Pada tahap hasil dan pembahasan berisi tahapan proses analisis manajemen risiko TI pada DISKOMINFO menggunakan tahapan proses domain APO12 yang sudah dipaparkan sebelumnya. Hasil dari penelitian manajemen risiko TI dengan domain APO12 pada framework COBIT 5 yaitu sebagai berikut:

a. APO12.01 Mengumpulkan data

Mengidentifikasi dan kemudian membuat daftar data tentang peristiwa risiko yang telah menyebabkan atau mungkin akan menyebabkan risiko terhadap TI. Daftar data risiko terkait TI bersifat relevan dari masalah, insiden yang ada, dan wawancara terkait dengan TI.[9]

Dari hasil wawancara teridentifikasi risiko TI sebagai berikut :

- Genset pada Data center belum otomatis, jadi server sering down pada saat adanya pemadaman listrik. Hal ini akan menyebabkan banyak kerugian antara lain mudah rusaknya perangkat TI, adanya kehilangan data dan terhambatnya operasional.

- Serangan Cyber crime berupa deface website, yaitu upaya merubah tampilan website dinas oleh pihak yang tidak bertanggungjawab. Hacker atau penyerang bisa menimbulkan kerugian dengan menggunakan website untuk kepentingan atau tujuan lain seperti menyebarkan informasi yang menimbulkan kerugian.

- Keamanan sistem login Sosial Media Dinas yang tidak ditentukan wewenangnya.

- Koneksi jaringan yang masih menggunakan pihak luar, sehingga jika pihak penyedia mengalami kendala maka jaringan DISKOMINFO juga mengalami kendala.

- Serangan pada server.

- Tidak maksimalnya dokumentasi aplikasi dalam perancangan atau pengembangan aplikasi. Hal tersebut dapat menghambat proses pengembangan aplikasi selanjutnya.

- Perancangan antar muka aplikasi yang belum maksimal, menimbulkan human error dalam penggunaan aplikasi.

- Perangkat keras mengalami panas yang berlebihan (overheat) dikarenakan pendingin ruangan (AC) yang sudah rusak sehingga kondisi ruangan tidak mendukung.

- Kerusakan dan kehilangan data, dikarenakan server yang sering down mengakibatkan kerusakan pada perangkat penyimpanan.

- Potensi virus pada PC user.

Resiko-resiko tersebut dapat menghambat dalam pencapaian tujuan yang harus dicapai. Adapun tujuan DISKOMINFO yang harus dicapai terbagi dua kelompok menurut waktunya yaitu jangka Panjang dan jangka menengah, berikut tujuan tersebut :

Tujuan dan sasaran jangka menengah :

$\checkmark$ Memenuhi keperluan pendukung pelayanan agar kinerja perangkat daerah meningkat.

$\checkmark$ Pengadaan kebijakan pada DISKOMINFO sesuai bidang yang ada meliputi bidang statistik, bidang persandian, bidang komunikasi informasi dan bidang tata kelola Pemerintahan elektronik (e-government)

$\checkmark$ Peningkatan pelayanan komunikasi dan informasi.

$\checkmark$ Peningkatan pelayanan e-goverment.

$\checkmark$ Pengadaan dan pengelolaan pada data statistik sektoral.

$\checkmark$ Peningkatan penyelenggaraan persandian untuk pengamanan informasi. 
Pengembangan model hubungan komunikasi sandi antar perangkat daerah.

Tujuan dan sasaran jangka Panjang terbagi sesuai program yang ada antara lain yaitu:

Tabel 1. Tujuan dan Sasaran Jangka Panjang.

\begin{tabular}{|c|c|}
\hline & Tujuan dan sasaran jangka Panjang \\
\hline $\begin{array}{l}\text { am pengembang } \\
\text { nasi, media masa dan } \\
\text { nikasi. }\end{array}$ & $\begin{array}{l}\text { 1. Melakukan pembinaan serta Pengembangan } \\
\text { pada Jaringan Komunikasi dan Informasi. } \\
\text { 2. Melakukan pembinaan serta Pengembangan } \\
\text { pada sumberdaya komunikasi dan informasi } \\
\text { sebagai upaya peningkatan SDM dalam } \\
\text { pengelolaan. } \\
\text { 3. Penyediaan Jasa Akses Internet } \\
\text { (Terbangunnya Akses Internet di Semua } \\
\text { SKPD (Satuan Kerja Perangkat Daerah) } \\
\text { Dan Fasilitas Publik dan Penyediaan Jasa } \\
\text { Akses Internet Jaringan Tertutup. }\end{array}$ \\
\hline $\begin{array}{l}\text { Program fasilitasi upaya } \\
\text { pengembangan SDM di } \\
\text { bidang komunikasi dan } \\
\text { informasi. }\end{array}$ & $\begin{array}{l}\text { 1. Memberi Pelatihan atau edukasi SDM } \\
\text { dalam bidang komunikasi dan informasi } \\
\text { 2. Pengembangan SDM TIK berupa } \\
\text { workshop, Pendidikan, sertifikasi dan } \\
\text { pelatihan bagi SDM TIK. }\end{array}$ \\
\hline $\begin{array}{lcr}\text { Program } & \text { kerjasama } & \text { pada } \\
\text { informasi } & \text { dengan } & \text { media } \\
\text { massa. } & & \\
\end{array}$ & $\begin{array}{l}\text { 1. Penyebaran informasi mengenai } \\
\text { penyelenggaraan pada pemerintah daerah } \\
\text { Salatiga. } \\
\text { 2. Penyampaian informasi terkait penyuluhan } \\
\text { yang berguna bagi masyarakat. }\end{array}$ \\
\hline $\begin{array}{l}\text { engembangan data } \\
\text { nasi. }\end{array}$ & $\begin{array}{l}\text { Perancangan dan pengumpulan data atau } \\
\text { informasi kebutuhan penyusunan dokumen } \\
\text { perencanaan. }\end{array}$ \\
\hline $\begin{array}{l}\text { Program } \\
\text { pemanfaatan } \\
\text { informasi }\end{array}$ & $\begin{array}{l}\text { 1. Penyelenggaraan Layanan Nama Domain } \\
\text { 2. Pemeliharaan Infrastruktur TIK } \\
\text { 3. Pengembangan dan Pengelolaan Aplikasi } \\
\text { 4. Penyediaan Layanan Command Center. }\end{array}$ \\
\hline $\begin{array}{lr}\text { Program } & \text { penyelenggaraan } \\
\text { persandian } & \text { untuk } \\
\text { pengamanan } & \end{array}$ & \begin{tabular}{crr}
\multicolumn{2}{l}{ Penyelenggaraan } & mengenai \\
Informasi & dan & Tingkat \\
Informasi & yang & memiliki
\end{tabular} \\
\hline
\end{tabular}

\section{b. APO12.02 Menganalisis risiko atau mengembangkan resiko.}

Memaparkan pandangan aktual atau informasi yang dapat memperkuat risiko TI terkait relevansi dan aktualnya risiko TI. Analisis risiko bertujuan untuk mendukung keputusan mengenai perlakuan risiko dan evaluasi terhadap risiko tersebut.

Analisis risiko ini akan dipertimbangkan melalui semua faktor risiko dengan meninjau dari aspek risiko yaitu dampak risiko dan peluang risiko. Pada tahap ini dilakukan pengukuran tingkat risiko melalui dampak dan peluang risiko. Dimana peluang dalam risiko memiliki nilai kecil, sedang, dan tinggi. Sedangkan nilai dari dampak risiko meliputi dampak ringan, sedang 
dan berat. Dari peluang dan dampak risiko tersebut pemahaman dan evaluasi mengenai temuan risiko lebih dalam untuk selanjutnya dapat menemukan hasil masukan bagi evaluasi risiko.

Tabel 2. Hasil Analisis Risiko yang Ditemukan.

\begin{tabular}{|c|c|c|c|c|}
\hline No. & Risiko & Pengendalian & Peluang & Dampak \\
\hline 1 & $\begin{array}{l}\text { Genset pada Data center } \\
\text { belum otomatis }\end{array}$ & $\begin{array}{l}\text { Petugas yang bertanggung jawab } \\
\text { di haruskan selalu siaga saat } \\
\text { terjadinya listrik padam. }\end{array}$ & tinggi & berat \\
\hline 2 & $\begin{array}{l}\text { Cyber crime berupa deface } \\
\text { Website (upaya mengubah } \\
\text { tampilan website secara } \\
\text { ilegal). }\end{array}$ & $\begin{array}{l}\text { Memberikan pemberitahuan } \\
\text { untuk mengupdate Aplikasi } \\
\text { Browser yang digunakan. }\end{array}$ & sedang & sedang \\
\hline 3 & $\begin{array}{l}\text { Keamanan Login Sosial } \\
\text { Media Dinas }\end{array}$ & $\begin{array}{l}\text { Memperjelas wewenang } \\
\text { mengenai tanggung jawab admin } \\
\text { akun sosial media dinas. }\end{array}$ & sedang & ringan \\
\hline 4 & $\begin{array}{l}\text { Koneksi jaringan masih } \\
\text { menggunakan pihak luar }\end{array}$ & $\begin{array}{l}\text { Melakukan perancangan } \\
\text { perencanaan pembangunan sistem } \\
\text { jaringan. }\end{array}$ & sedang & sedang \\
\hline 5 & Serangan Pada Server & $\begin{array}{l}\text { Melakukan pengamanan data } \\
\text { untuk dapat digunakan kembali } \\
\text { setelah adanya serangan server. }\end{array}$ & tinggi & Berat \\
\hline 6 & $\begin{array}{l}\text { Tidak maksimalnya } \\
\text { dokumentasi aplikasi }\end{array}$ & $\begin{array}{l}\text { Mengadakan peraturan mengenai } \\
\text { kelengkapan } \\
\text { aplikasi }\end{array}$ & sedang & Sedang \\
\hline 7 & $\begin{array}{l}\text { Antar muka beberapa } \\
\text { aplikasi kurang maksimal }\end{array}$ & $\begin{array}{l}\text { Membuat tampilan antarmuka } \\
\text { aplikasi dengan user yang } \\
\text { sederhana dan mudah digunakan } \\
\text { sesuai fungsinya. }\end{array}$ & kecil & Sedang \\
\hline 8 & $\begin{array}{l}\text { Hardware overheat karena } \\
\text { AC yang sudah rusak. }\end{array}$ & $\begin{array}{llr}\begin{array}{l}\text { Melakukan maintenance pada } \\
\text { hardware secara tepat dan } \\
\text { berkala. }\end{array} & & \\
\end{array}$ & sedang & Sedang \\
\hline 9 & $\begin{array}{l}\text { kerusakan dan kehilangan } \\
\text { data }\end{array}$ & $\begin{array}{l}\text { Melakukan backup secara berkala } \\
\text { agar dapat di restore. }\end{array}$ & sedang & berat \\
\hline 10 & $\begin{array}{l}\text { potensi adanya virus pada } \\
P C \text { user }\end{array}$ & $\begin{array}{l}\text { Tidak sembarangan melakukan } \\
\text { akses terhadap situs. }\end{array}$ & kecil & sedang \\
\hline
\end{tabular}

c. APO12.03 Maintain A Risk Profile atau Menjaga atau memelihara profil risiko.

Menjaga semua profil risiko yang di dapat dari informasi analisis data risiko TI yang ada. Dalam kegiatan ini yang dilakukan antara lain:

a. Mengidentifikasi proses bisnis dan ketergantungan pada risiko TI yang ada baik dari berbagai aspek meliputi aplikasi infrastruktur, catatan manual kritis, fasilitas, dan pihak luar yang terkait (agen outsourcing).

b. Menentukan sumber daya infrastruktur TI dan layanan TI yang menopang proses bisnis.

c. Mengidentifikasi keterkaitan koneksi lemah.

d. Menentukan serangkaian indikator dan pemantauan terhadap risiko TI dan tren risiko saat ini berdasarkan data profil risiko TI.

e. Mengumpulkan informasi kejadian risiko, 
f. Memasukan informasi peristiwa risiko TI yang terjadi ke dalam profil risiko perusahaan.

Hasil yang diperoleh pada tahap ini dapat dilihat pada tingkat risiko pada kejadian risiko.

Tabel 3. Hasil Tahap Maintenance A Risk Profile

\begin{tabular}{|c|l|c|}
\hline No. & \multicolumn{1}{|c|}{ Risiko } & Tingkat Risiko \\
\hline 1 & Genset pada Data center belum otomatis & Tinggi \\
\hline 2 & $\begin{array}{l}\text { Cyber crime berupa deface Website (upaya mengubah tampilan } \\
\text { website secara ilegal). }\end{array}$ & Sedang \\
\hline 3 & Keamanan Login Sosial Media & Sedang \\
\hline 4 & Koneksi jaringan masih menggunakan pihak luar & Sedang \\
\hline 5 & Serangan Pada Server & Tinggi \\
\hline 6 & Tidak maksimalnya dokumentasi aplikasi & Sedang \\
\hline 7 & Antar muka beberapa aplikasi kurang maksimal & Kecil \\
\hline 8 & Hardware overheat karena AC yang sudah rusak. & Sedang \\
\hline 9 & kerusakan dan kehilangan data & Sedang \\
\hline 10 & potensi adanya virus pada $P C$ user & Kecil \\
\hline
\end{tabular}

\section{d. APO12.04 Articulate Risk/Mengkomunikasikan risiko.}

Menginformasikan kepada pemangku kepentingan mengenai efektivitas manajemen risiko TI, rentang kerugian dan keuntungan mengenai risiko TI, peraturan dan juga dampak lain terkait risiko TI. Memeriksa penilaian pihak ketiga, audit internal dan penjamin obyektif untuk dimasukan ke dalam profil risiko

Melaporkan profil risiko yang ditemukan seperti keefektifan manajemen risiko, efektivitas pengendalian dan dampak terhadap profil risiko. Dan juga memberi pemahaman kepada pemangku kepentingan tentang skenario terburuk, reputasi dan pertimbangan hukum atau peraturan.

Sehingga pada tahap ini menghasilkan deskripsi peluang untuk dapat dipertimbangkan oleh pemangku kepentingan terkait respon tepat dan tepat waktu. 
Tabel 4. Artikulasi Risiko

\begin{tabular}{|c|c|c|c|}
\hline No. & Risiko & Peluang & Rekomendasi \\
\hline 1 & $\begin{array}{l}\text { Genset pada Data center } \\
\text { belum otomatis }\end{array}$ & Tinggi & $\begin{array}{l}\text { Menyediakan genset otomatis pada Data } \\
\text { center }\end{array}$ \\
\hline 2 & $\begin{array}{l}\text { Cyber crime berupa } \\
\text { deface Website upaya } \\
\text { mengubah tampilan } \\
\text { website secara ilegal). }\end{array}$ & Sedang & $\begin{array}{l}\text { a. Melakukan maintenance untuk } \\
\text { menemukan bug (Kesalahan / error) } \\
\text { pada website yang berkemungkinan } \\
\text { mengakibatkan terjadinya cyber } \\
\text { crime website. } \\
\text { b. Memperbaiki bug yang ditemukan. } \\
\text { c. Melakukan audit keamanan pada } \\
\text { website. } \\
\text { d. Melakukan update terhadap } \\
\text { Aplikasi browser secara rutin setiap } \\
\text { ada versi } \\
\text { Aplikasi browser di setting untuk } \\
\text { mengupdate secara otomatis } \\
\text { Pengaturan pada aplikasi untuk } \\
\text { memberi notif jika ada versi terbaru. }\end{array}$ \\
\hline 3 & $\begin{array}{l}\text { Keamanan Login Sosial } \\
\text { Media }\end{array}$ & Sedang & $\begin{array}{l}\text { a. Menunjuk kepada salah satu } \\
\text { pegawai untuk di beri tanggung } \\
\text { jawab sebagai admin } \\
\text { Mengganti password secara berkala } \\
\text { b. Menyediakan device (peralatan) } \\
\text { khusus untuk mengelola Sosial } \\
\text { media dinas. } \\
\text { c. Tidak diperbolehkan login akun } \\
\text { sosial media dinas menggunakan } \\
\text { device lain. }\end{array}$ \\
\hline 4 & $\begin{array}{l}\text { Koneksi jaringan masih } \\
\text { menggunakan pihak luar }\end{array}$ & Sedang & 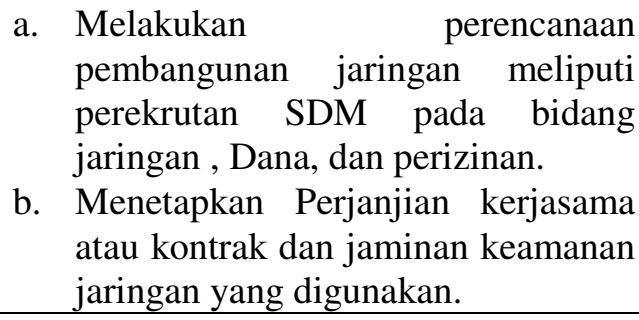 \\
\hline 5 & Serangan Pada Server & Tinggi & $\begin{array}{l}\text { Mengadakan rencana pengadaan firewall } \\
\text { pada server. }\end{array}$ \\
\hline 6 & $\begin{array}{l}\text { Tidak maksimalnya } \\
\text { dokumentasi aplikasi }\end{array}$ & Sedang & $\begin{array}{l}\text { Menetapkan peraturan mengenai } \\
\text { kelengkapan dokumentasi aplikasi bagi } \\
\text { perancang maupun pengembang baik } \\
\text { dari pihak luar atau dalam dinas. }\end{array}$ \\
\hline 7 & $\begin{array}{l}\text { antar muka beberapa } \\
\text { aplikasi kurang maksimal }\end{array}$ & Kecil & $\begin{array}{l}\text { a. Membuat tampilan antar muka } \\
\text { aplikasi (User Interface) yang } \\
\text { bersifat user friendly. } \\
\text { b. Melakukan sosialisasi mengenai } \\
\text { aplikasi kepada user. }\end{array}$ \\
\hline
\end{tabular}




\begin{tabular}{|c|c|c|c|}
\hline 8 & $\begin{array}{l}\text { Hardware overheat } \\
\text { karena AC yang sudah } \\
\text { rusak. }\end{array}$ & Sedang & $\begin{array}{l}\text { a. Melakukan pengadaan barang } \\
\text { seperti pendingin ruangan. } \\
\text { b. Melakukan maintenance pada } \\
\text { hardware secara tepat dan berkala. }\end{array}$ \\
\hline 9 & $\begin{array}{l}\text { kerusakan dan kehilangan } \\
\text { data }\end{array}$ & Sedang & $\begin{array}{l}\text { a. Menjaga perangkat penyimpanan } \\
\text { data (hardisk) agar selalu dalam } \\
\text { kondisi baik. } \\
\text { b. Melakukan backup secara berkala } \\
\text { agar dapat di restore. }\end{array}$ \\
\hline 10 & $\begin{array}{l}\text { potensi adanya virus pada } \\
\text { PC user }\end{array}$ & Kecil & 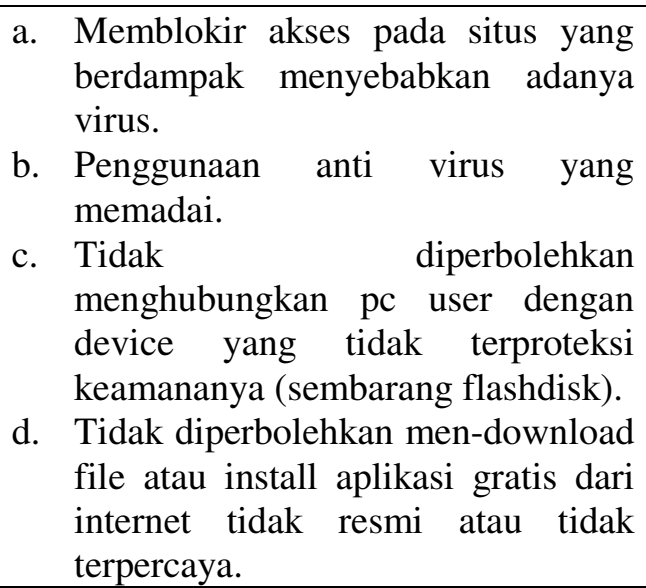 \\
\hline
\end{tabular}

e. APO12.05 Define A Risk Management Action Portfolio atau menentukan portofolio pada tindakan manajemen risiko.

Mengelola penanganan atau tindakan yang diambil untuk mengurangi risiko sebagai portofolio. Tahap ke-5 ini terdapat beberapa kegiatan yaitu:

- Mempertahankan pencatatan aktivitas risiko, pengendalian untuk mengelola risiko.

- Memeriksa setiap individu, memantau risiko dan menghimpun atau menerima dampaknya untuk berjalan dengan tingkat toleransi setiap individu.

- Merancang dan menetapkan proposal untuk pengendalian, pengurangan, pemetaan risiko TI dan memungkinkan peluang adanya tindakan strategis dengan mempertimbangkan biaya yang diperlukan, manfaat yang di dapat, dampak pada profil risiko dan peraturan perusahaan yang harus ditaati.

Untuk menentukan tindakan terhadap risiko mengacu pada, macam-macam cara untuk menangani risiko yaitu: [10]

$\checkmark$ Menghindari risiko atau Menyingkirkan (risk avoidance), yaitu tindakan menghentikan kegiatan yang mengakibatkan adanya risiko TI.

$\checkmark$ Berbagi atau memecah risiko (risk transfer/risk Sharing), merupakan tindakan yang diambil untuk memperkecil adanya risiko ataupun dampak dari risiko.

$\checkmark$ Mitigasi risiko (mitigation) atau pengurangan risiko (risk reduction), yaitu melakukan tindakan terhadap risiko untuk mengurangi kemungkinan timbulnya risiko, atau mengurangi dampak kerusakan risiko bila terjadi.

$\checkmark$ Menerima risiko (risk acceptance), yaitu tidak melakukan tindakan apapun terhadap risiko tersebut. 
Tabel 5. Tindakan Terhadap Risiko

\begin{tabular}{|c|c|c|c|c|}
\hline No. & Risiko & Pengendalian & Peluang & Tindakan \\
\hline 1 & $\begin{array}{l}\text { Genset pada Data } \\
\text { center belum } \\
\text { otomatis }\end{array}$ & $\begin{array}{l}\text { Petugas yang bertanggung jawab } \\
\text { di haruskan selalu siaga saat } \\
\text { terjadinya listrik padam }\end{array}$ & tinggi & Mitigasi \\
\hline 2 & $\begin{array}{l}\text { Cyber crime berupa } \\
\text { deface Website } \\
\text { (upaya mengubah } \\
\text { tampilan website } \\
\text { secara ilegal). }\end{array}$ & $\begin{array}{l}\text { Memberikan pemberitahuan } \\
\text { untuk mengupdate Aplikasi } \\
\text { Browser yang digunakan }\end{array}$ & sedang & Menghindari \\
\hline 3 & $\begin{array}{l}\text { Keamanan Login } \\
\text { Sosial Media }\end{array}$ & $\begin{array}{l}\text { Memperjelas wewenang } \\
\text { mengenai tanggung jawab admin } \\
\text { akun sosial media dinas. }\end{array}$ & sedang & Menghindari \\
\hline 4 & $\begin{array}{l}\text { Koneksi jaringan } \\
\text { masih } \\
\text { menggunakan } \\
\text { pihak luar }\end{array}$ & $\begin{array}{lr}\text { Melakukan } & \text { perancangan } \\
\text { perencanaan } & \text { pembangunan } \\
\text { sistem jaringan. } & \end{array}$ & sedang & Mitigasi \\
\hline 5 & $\begin{array}{l}\text { Serangan Pada } \\
\text { Server }\end{array}$ & $\begin{array}{l}\text { Melakukan pengamanan data } \\
\text { untuk dapat digunakan kembali } \\
\text { setelah adanya serangan server. }\end{array}$ & tinggi & Mitigasi \\
\hline 6 & $\begin{array}{l}\text { Tidak maksimalnya } \\
\text { dokumentasi } \\
\text { aplikasi }\end{array}$ & $\begin{array}{l}\text { Mengadakan peraturan mengenai } \\
\text { kelengkapan } \\
\text { aplikasi }\end{array}$ & sedang & Menghindari \\
\hline 7 & $\begin{array}{l}\text { antar muka } \\
\text { beberapa aplikasi } \\
\text { kurang maksimal }\end{array}$ & $\begin{array}{l}\text { Membuat tampilan antarmuka } \\
\text { aplikasi dengan user yang } \\
\text { sederhana dan mudah digunakan } \\
\text { sesuai fungsinya. }\end{array}$ & kecil & Menghindari \\
\hline 8 & $\begin{array}{l}\text { Hardware overheat } \\
\text { karena AC yang } \\
\text { sudah rusak. }\end{array}$ & $\begin{array}{l}\text { Melakukan maintenance pada } \\
\text { hardware secara tepat dan } \\
\text { berkala dan melakukan } \\
\text { perbaikan ruangan dengan } \\
\text { pengadaan AC. }\end{array}$ & sedang & Mitigasi \\
\hline 9 & $\begin{array}{l}\text { kerusakan dan } \\
\text { kehilangan data }\end{array}$ & $\begin{array}{l}\text { Melakukan backup secara } \\
\text { berkala agar dapat di restore. }\end{array}$ & sedang & Mitigasi \\
\hline 10 & $\begin{array}{l}\text { potensi adanya } \\
\text { virus pada } P C \text { user }\end{array}$ & $\begin{array}{l}\text { Tidak sembarangan melakukan } \\
\text { akses terhadap situs. }\end{array}$ & kecil & Menghindari \\
\hline
\end{tabular}

\section{f. APO12.06 Respond To Risk atau menanggapi risiko.}

Tanggapan terhadap risiko secara tepat waktu untuk membatasi kerugian yang dapat ditimbulkan akibat risiko yang sudah terdokumentasi. Tanggapan terhadap risiko dapat berupa tindakan yang meringankan risiko. Dalam meringankan resiko menggunakan profil risiko yang merupakan hasil dari penilaian risiko dengan rekomendasi tanggapan.

Dengan ini terdapat beberapa kegiatan yaitu:

- Melaporkan kategori inisiden dan kerugian terkait TI dengan batas toleransi risiko kepada pemangku kepentingan dan sebagai pembaruan profil risiko.

- Mengidentifikasi dampak risiko dan menemukan akar penyebab risiko. 
- Mengkomunikasikan akar masalah, perbaikan proses, dan persyaratan untuk tindakan terhadap risiko tambahan, dan juga rencana tindakan yang tepat untuk menekan dampak risiko kepada pemangku kepentingan.

- Menerapkan rencana solusi dari risiko yang tepat untuk mengurangi dampak dari risiko.

Oleh karena itu untuk meringankan dampak risiko tepat waktu, pihak berwenang perlu mengambil tindakan respon terhadap risiko berdasarkan rekomendasi tindakan pada Tabel4.

\section{KESIMPULAN}

Berdasarkan penelitian yang telah dibahas mengenai analisis manajemen risiko teknologi informasi di Dinas Komunikasi dan Informatika melalui tahap analisis manajemen risiko menggunakan domain Cobit 5 yaitu APO 12, maka dapat diambil kesimpulan bahwa tingkat risiko yang tinggi pada analisis ini yaitu genset yang belum otomatis dan serangan pada server sehingga diperlukan upaya pengadaan genset otomatis dan firewall pada server sebagai tindakan rekomendasi. Maka dari itu pihak DISKOMINFO sebaiknya dapat segera melakukan implementasi rekomendasi terhadap temuan risiko yang telah disebutkan sebagai tindakan tanggapan agar memperkecil atau menghilangkan tingkat risiko yang di hadapi dan juga sebagai tindakan perbaikan risiko yang bermanfaat pada peningkatan kinerja

\section{SARAN}

Adapun saran untuk penelitian selanjutnya mengenai analisis manajemen risiko mencakup juga pada SDM (Sumber daya Manusia) sebagai pengguna atau pelaku yang bersangkutan dengan TI agar dapat lebih menyeluruh cakupan analisisnya untuk memperoleh lebih banyak rekomendasi dalam memperbaiki manajemen risiko pada DISKOMINFO.

\section{DAFTAR PUSTAKA}

[1] C. R. Thenu, Prilly Peshaulia, Agustinus Fritz Wijaya, 2020, "Analisis Manajemen Risiko Teknologi Informasi Menggunakan Cobit 5 (Studi Kasus: PT Global Infotech),” J. Bina Komput., Vol. 2, No. 1, pp. 1-13.

[2] F. Karuniawati, L. Supriono, and L. Fatmawati, 2017, "Penggunaan Cobit 5 Untuk Penilaian Risiko Dalam Situs E-Marketplace di Indonesia,” Pilar Teknol., Vol. 2, No. September, pp. 1-5.

[3] H. Purwanto and N. Yuanita, 2019, "Penerapan Framework COBIT 5 pada Tata Kelola Teknologi Informasi PT Pindad (PERSERO) (Studi Kasus: Domain APO11 \& APO12),” J. LPKIA, Vol. 12, No. 1, pp. 56-60.

[4] A. S. Agtika, Y. T. Mursityo, and A. Rachmadi, 2019, "Evaluasi Manajemen Risiko Teknologi Informasi pada Badan Perencanaan, Penelitian dan Pengembangan (Barenlitbang) Kota Malang Menggunakan COBIT 5 Domain EDM03 dan APO12," J. Pengemb. Teknol. Inf. dan Ilmu Komput., Vol. 3, No. 5, pp. 4218-4225, [Online]. Available: http://j-ptiik.ub.ac.id/index.php/j-ptiik/article/view/5169. 
[5] J. T. FORCE and T. INITIATIVE, 2011, "Managing Information Security Risk Organization, Mission, and Information System View," NIST Spec. Publ. 800-39, No. March, doi: 10.1108/k.2011.06740caa.012.

[6] A. M. Syuhada, 2021, "Kajian Perbandingan Cobit 5 Dengan Cobit 2019 Sebagai Framework Audit Tata Kelola Teknologi Informasi," J. Ilm. Indones., Vol. 6, No. 1, pp. $30-39$.

[7] F. S. Sulaeman, 2015, “Audit Sistem Informasi Framework Cobit 5," Media J. Inform., Vol. 7, No. 2, pp. 37-42, doi: 10.31219/osf.io/yp5u2.

[8] H. Wijaya, 2019, "2 Metode-metode Penelitian Dalam Penulisan Jurnal Ilmiah Elektronik," pp. 21-40.

[9] R. Astuti, 2018, "Implementasi Manajemen Risiko Sistem Informasi Menggunakan Cobit 5," Media Inform., Vol. 17, No. 1, pp. 18-28.

[10] [Online]. Available: https://www.academia.edu/9860893/

Proses_Manajemen_Risiko /alfa sitetsu. [accessed 5 April 2021] 